\section{Acknowledgements}

Financial support was provided by National Institutes of Health grant SP 30-CA 13330 and MMC Department of Urology funds. We thank Jamil Rehman, Michael O. Davia, Victor Hatcher and Diane DiTrapani for their help and the MMC Department of Urology Nursing Staff for assistance with phlebotomy.

1. Rinker-Schaeffer, C.W., Partin, A.W., Isaacs, W.B., Coffey, D.S. \& Isaacs, J.T. Molecular and cellular changes associated with the acquisition of metastatic ability by prostatic cancer cells. Prostate 25, 249-265 (1994).

2. Dalal, B.I., Keown, P.A. \& Greenberg A.H. Immunocytochemical localization of secreted transforming growth factor- $\beta 1$ to the advancing edges of primary tumors and to lymph node metastases of human mammary carcinoma. Am. J. Pathol. 143, 381-389 (1993).

3. Truong, L.D. et al. Association of transforming growth factor- $\beta 1$ with prostate cancer: An immunohistochemical study. Hum. Pathol. 24, 4-9 (1993).

4. Smith, J.A. Jr \& Scaletsky, R. Future directions in tumor marker technology for prostate cancer. Urol. Clin. North Am. 20, 771-777 (1993).

5. Thompson, T.C. Growth factors and oncogenes in prostate cancer. Cancer Cells 2, 345-354 (1990).

6. Merz, V.W. et al. Elevated transforming growth factor- $\beta 1$ and b3 mRNA levels are associated with ras+ and myc- induced carcinomas in reconstituted mouse prostate: Evidence for a paracrine role during progression. Molec. Endocrinol. 5, 503-513 (1991).

7. Steiner, M.S. \& Barrack, E.R. Transforming growth factor- $\beta 1$ overproduction in prostate cancer: Effects on growth in vivo and in vitro. Molec. Endocrinol. 6, 15-25 (1992).

8. Ikeda, T., Lioubin, M.N. \& Marquardt, H. Human transforming growth factor type b2: Production by a prostatic adenocarcinoma cell line, purification and initial characterization. Biochemistry 26, 2406-2410 (1987).

9. Shirai, Y. et al. Elevated levels of plasma transforming growth factor- $\beta 1$ in patients with hepatocellular carcinoma. Jap. J. Cancer Res. 83, 676-679 (1992).

10. Carter, H.B., Piantadosi, S. \& Isaacs, J.I. Clinical evidence for and implications of the multistep development of prostate cancer. J. Urol. 143, 742-746 (1990).

11. Nishiya, M., Miller, G.J., Lookner, D.H., \& Crawford, E.D. Prostate specific antigen density in patients with histologically proven prostate carcinoma. Cancer 74, 3002-3009 (1994).

12. Thompson, T.C. et al. Transforming growth factor $\beta 1$ as a biomarker for prostate cancer. J. cell. Biochem. 16, H, 54-61 (1992).

13. Goldstein, D., O'Leary, M. \& Mitchen, J. Effects of interferon beta and transforming growth factor beta on prostatic cell lines. /. Urol. 146 , 1173-1177, (1991).

14. Welch, D.R., Fabra, A. \& Nakajima, M. Transforming growth factor $\beta 1$ stimulates mammary adenocarcinoma cell invasion and metastatic potential. Proc. natn. Acad. Sci. U.S.A. 87, 7678-7682 (1990).

\title{
Coxsackie virus and diabetes revisited
}

To the editor - The recent News \& Views article that considered the role of Coxsackievirus in insulin-dependent diabetes mellitus (IDDM) outlined a mechanism known as molecular mimicry, in which an immune response directed against an environmental agent stimulates a cross-reactive response against a homologous peptide from an autoantigen. In the case of IDDM, an epitope of glutamic acid decarboxylase (GAD65) shares strong sequence similarity with the $\mathrm{PC} 2$ protein of Coxsackie B viruses, including an exact sixamino acid match, PEVKEK. The News \& Views described data from two articles ${ }^{2,3}$, demonstrating a potential for T-cell crossreactivity between GAD65 and Coxsackie PC2 PEVKEK peptides. Reference was also made to our recent work in this field and we wish to clarify the interpretation of our results.

We have undertaken a comparison of the GAD65 amino acid sequence against the OWL protein database ${ }^{4}$, identified 17 regions of similarity to virus proteins, and investigated $\mathrm{T}$-cell proliferative responses to 13 of these viruses in subjects with IDDM. Our data (manuscript in preparation) suggest that significant differences in the frequency of positive response and magnitude of response occur only for Coxsackie B viruses and adenovirus. Of the 13 viruses studied, only the Coxsackie $B$ viruses exhibited sequence homology in the PEVKEK region.

Current evidence suggests that there are two dominant T-cell epitopes for GAD65 in IDDM. The first occurs at amino acids $509-543$ in the NOD mouse, and in a region between 473 and 555 in humans ${ }^{5}$. We did not find any virus protein homology in this region, but have previously noted homology to the cellular stress protein hsp60, which may also be an antigen in $\mathrm{IDDM}^{6}$. The second epitope contains the PEVKEK sequence and has now been confirmed as an epitope in both NOD mouse $^{2}$ and human IDDM ${ }^{3}$. Our data using T-cell proliferation assays strengthen the support for a Coxsackie infection as a triggering event in human IDDM. Although serological studies have failed to find significant titres of Coxsackie B virus-specific immunoglobulin, this could be a consequence of the long prodromal period before clinical symptoms are observed.

Our evidence indicates that proliferative responses to Coxsackie $B$ viruses are found in the majority of subjects with IDDM. The case for Coxsackie B virus involvement in IDDM is in our view stronger than that implied in the recent News \& Views article by Solimena and De Camilli.

DAVID B. JONES Nigel W. Armstrong

Department of Human Anatomy and Cell Biology University of Liverpool, P.O. Box 147 Liverpool L69 3BX, UK

1. Solimena, M. \& De Camilli, P. Coxsackieviruses and diabetes. Nature Med. 1, 25-26 (1995).

2. Atkinson, M.A. et al. Autoimmunity to two forms of glutamate decarboxylase in insulin-dependent diabetes mellitus. J. clin. Invest. 94, 2125-2129 (1994).

3. Tian, J. et al. T cell cross-reactivity between Coxsackie virus and glutamate decarboxylase is assoicated with a murine diabetes susceptibility. $J$. exp. Med. 180, 1979-1984 (1994).

4. Kaufmann, D.L. et al. Spontaneous loss of T-cell tolerance to glutamic acid decarboxylase in murine insulin-dependent diabetes. Nature 366, 69-72 (1993).

5. Lohmann, T. et al. unodominant epitopes of glutamic acid decarboxylase 65 and 67 in insulin-dependent diabetes mellitus. Lancet 343, 1607-1608 (1994).

6. Jones, D.B. \& Armstrong, N.W. [GAD 65 epitopes in in insulin-dependent diabetes mellitus.] Lancet 343, 1168-1169 (1994).

\section{LETTERS TO THE EDITOR}

Nature Medicine encourages brief letters to the editor on topics that have been reported in previous issues or on subjects of current interest to the biomedical research community.

Letters of no more than 800 words should be addressed to:

Letters Editor, Nature Medicine,

1234 National Press Building, Washington, DC 20045.

FAX: (202) 628-1609 or e-mail letters@naturedc.com 